\title{
Film Review
}

\section{BULLY \\ A Bullying Prevention Project - Educator's DVD \& Toolkit (2011) http://www.thebullyproject.com/}

\author{
Lee Hirsch - Director/Producer/Cinematographer/Writer \\ Cynthia Lowen - Producer/Writer \\ The Weinstein Company
}

Dr. John Caruso, Jr. Media Reviews Editor

"Bully" forces you to confront not the cruelty of specific children

- who have their own problems, and their good sides as well but rather the extent to which that cruelty is embedded in our schools and therefore in our society as a whole.

NY Times Movie Review by A.O. Scott (29 March 2012)

In 94 minutes Lee Hirsch, director of Bully, and Cynthia Lowen, producer, share five heart wrenching vignettes, four of which were filmed in lower socio-economic rural

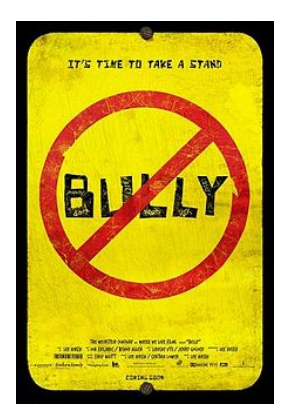
public school communities during 2009-2010. They construct a montage of bullying victims, reactions by their families and friends, and the failure of inept, defensive, and patronizing school administrators to address acts that led to two student suicides. The film chronicles the efforts of survivors to raise public consciousness about bullying and urges everyone to help defend its silent victims. Bully is more than a film. It is part of an articulated grassroots movement to transform the social and emotional environments of communities that tolerate the antecedents and painful lifetime residues of bullying. The common wisdom is that everyone opposes bullying, some excuse it as a rite of passage, but most are unwilling to do anything to prevent it.

The video Bully is available on DVD in an educator's kit in two versions with English and Spanish subtitles. The original 94-minute version is rated PG-13. A 47-minute version is designed for younger viewers without graphic language and the suicides of two bullying victims. The $\$ 30-$ kit provides a wealth of materials and

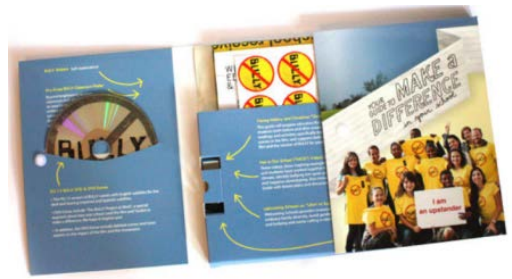


hotlinks to cogent sites that examine bullying from numerous perspectives. The kit contains both versions of the film, an educator's guide on a 1-GB flash drive to guide discussions of the film before and after, 16 pages of lamented explanations of antibullying awareness and procedures, 50 anti-bullying sticker decals, a synopsis of the companion book, two $36 " \times 24$ " anti-bullying wall posters, and other educational materials.

National data indicate that more than 13-million American children from diverse racial, social, ethnic, religious, economic, and sexual orientation backgrounds are bullied each year. Most of the victims suffer in silence, trying to minimize and conceal their daily humiliation. The few who speak out have to self-advocate because teachers, school administrators, and law enforcement buy into the social cliché that bullying is a normal stage of growing up and the acts and words will soon be forgotten. A tiny group harbor great resentment against those who tormented and rejected them or ignored their pleas for help. A few bullying victims respond violently to those who they believe brutalized them as evidenced by the school massacres in Columbine High School (1999), Virginia Polytechnic Institute (2007), and Sandy Hook Elementary School (2012).

The five stories in Bully unfold in overlapping integrated sequences without

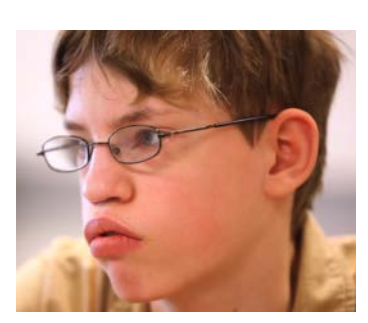
narration. The film begins with Alex Libby, a 12-year-old who lives in Sioux City, lowa, with his parents and four siblings. Alex is an articulate, gentle, caring, and loving son and brother whose goal in life is to have a friend, just one friend. $\mathrm{He}$ is so hungry for friendship that he excuses and describes the bullies as friends who are just messing around with him. The bullying is more than verbal taunts and teasing; it escalates into physical attacks of choking, punching, shoving, and stabbing him with pencils. The film makers were obligated to share the footage of the physical abuse on the daily school bus route with his parents and school officials. After watching the raw video, Alex's parents met with a school administrator to ask if she would place Alex on another bus route. The administrator explains to the parents she has ridden that bus route and the kids were just golden and well behaved. Throughout Bully, there are similar acts of classic denial. Bullying, bullies, and the school climate of bullying are minimized or dismissed as a rare occurrence rather than a tolerated subculture.

Kelby Johnson is a 16-year-old transgender male who

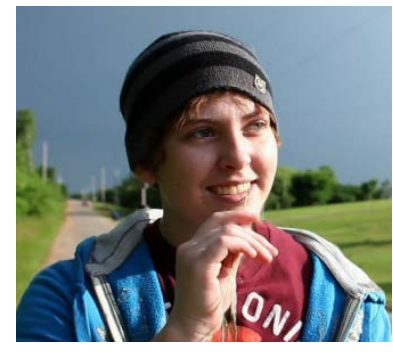
came out as a lesbian in the small town of Tuttle, OK. Kelby was an all-star high school athlete who went from a role model in sports to the status of a social pariah. Selfidentifying as a lesbian unleashed a hell storm of rejection and hatred. Students would not sit next to Kelby. They sent notes saying "faggots are not welcome here." A 
teacher reading a list of student names put Kelby in a separate category from her male and female classmates. Another teacher explained how in history "they burned fags at the stake." It appears that the school did nothing to reprimand teachers who discriminated against students. Kelby's parents were so stunned by the negative reactions that they were willing to move to another community. The Johnsons were dismayed by former friends in their church group who suddenly avoided them and even averted eye contact. Kelby, the victim who attempted suicide three times, consoled others, explaining that change begins with one person in one place. Supported by a small circle of school friends, Kelby said she wanted to be that person who changed others.

Ja'Meya Jackson, age 14, lives in Yazoo County, Mississippi. During the one-

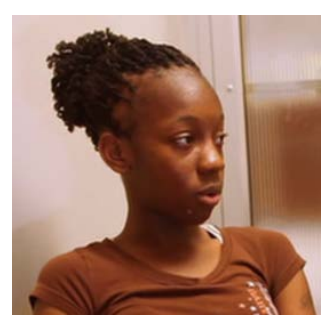
hour daily school bus trip, Ja'Meya was bullied and harassed. A group of students called her dumb and stupid, and one boy wanted to fight her. She was an honor student and an obedient child at home and won many athletic awards. One September morning, Ja'Meya pulled a handgun out of her schoolbag and walked up and down the bus aisle waving the pistol at those who tormented her. She had no intention of harming anyone, just warning them to stop the bullying. The gun was taken away by another student. Ja'Meya was arrested, incarcerated, and faced serious felony charges including multiple counts of kidnapping. After months of confinement in a juvenile facility with court-ordered psychological counseling, she had a closed court hearing. All charges were dropped, and Ja'Meya returned home subject to supervision.

The saga of Tina and David Long and their 17-year-old son Tyler was painful to watch. They live in Murray County, GA, where David retired from the US

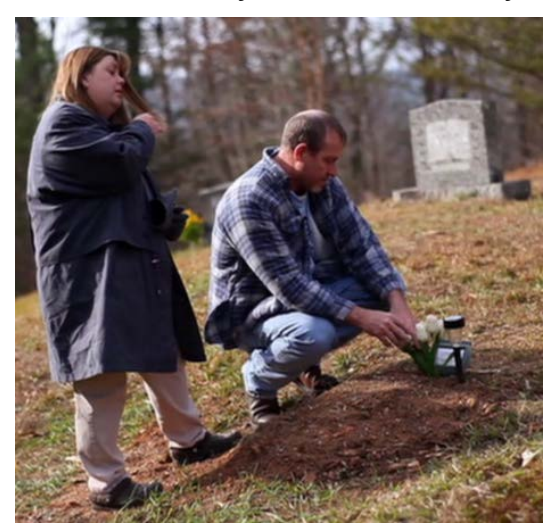
military. Tyler experienced years of torment in middle and high school, including suggestions that he should kill himself. The response from school officials and police resource officers in the school was to deny

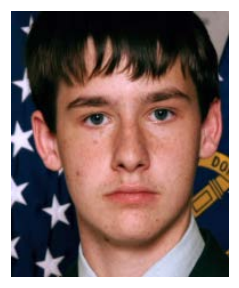
that bullying had occurred or was a problem. Unable to cope with the harassment, Tyler went into a closet at home and hanged himself. The school climate was so insensitive that the day after his death, students came to school with ropes around their neck and were not reprimanded. The Long family has taken a visible public stance demanding changes in the school climate and a community which was immersed in denial about bullying. David Long has taken a vow to go to his grave reminding the world of Tyler's victimization while devotedly protecting their other children from a similar fate. 
Kirk and Laura Smalley and their 11-year-old son Ty lived in Perkins, OK on a 40-acre family farm. Ty was a friendly boy of diminutive size that empowered bullies to call him shrimp or Tiny Tim, push him into wall lockers, pour milk on his head, and

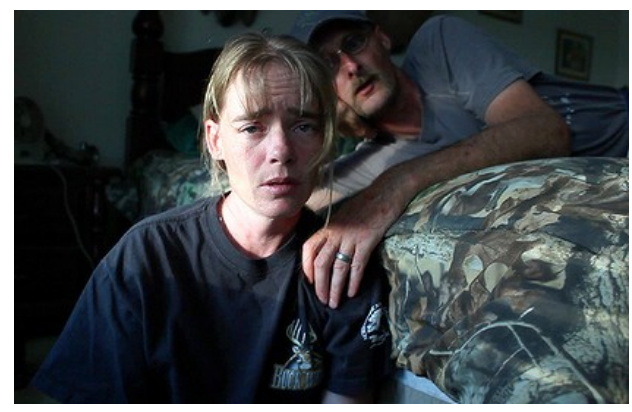
threaten to rape him. Laura Smalley worked in the school system and complained so often about Ty being bullied that the district threatened to fire her, yet there is not a single mention of Ty being bullied in his school file. After two years of torment, Ty confronted the boy who constantly victimized him. Without conducting an investigation, school officials suspended both boys for three days. Ty came home totally demoralized, went into his bedroom, and fatally shot himself in the head. His traumatized parents explained that Ty did not kill himself because he hated life. He was a victim of "bully-cide" because he could no longer endure the constant bullying. With the help of students from Oklahoma State University, Kirk and Laura Smalley, modest people of meager means, launched an antibullying organization and website Stand for the Silent (www.standforthesilent.org) that has gone global. The Smalleys have travelled around the nation, conducting antibullying vigils and reaching out to more than 800,000 students in 816 schools since their son died from bully-cide.

\section{Conclusion}

Four of the five vignettes in Bully anecdotally illustrate the pervasive nature of bullying in rural communities with all of its insidious and destructive manifestations. A holistic perspective would have included private, single-gender, and religious schools in higher socio-economic communities. Responses to bullying would reflect the educational levels and political influence of parents, administrators, school counselors, attorneys, and law enforcement agencies. There is no Federal law or regulation against bullying that would effectively monitor or manage the 14,000 local public school districts and thousands of private schools in the United States. Forty-nine states have antibullying laws, regulations, or guidelines, but the definitions, procedures, protocols, and punishments vary and often are not enforced until a felony occurs. There are great variances in the definitions of bullying, some states including cyberbullying and electronic harassment while others do not. Some states make it a misdemeanor crime, while others impose a non-judicial sanction or suspension. Some states require schools 
to include off-campus behaviors and others do not. These inconsistencies, due to many circumstances, indicate that education and law enforcement officials are failing to provide each PK-12 student with a safe learning environment, thus subjecting them to the potential of being bullied.

The video Bully earns a 9.0 on a scale of 10 in terms of expressing social conditions; engaging anecdotal dialogue; promoting self-reflection about bullying; and showing excellence in cinematography, pacing, sound, and editing. Schools and other civic organizations should consider purchasing the Educator's DVD and Toolkit and hosting a public showing and discussion of this powerful and moving documentary.

\section{Educational Resources}

State Anti-Bullying Laws

http://www.bullypolice.org/

Tools for Students, Parents, Educators, Advocates and Special Needs

http://www.thebullyproject.com/tools_and_resources

Stand for the Silent

http://www.standforthesilent.org/

Bullying: A Case Study in Ostracism

https://www.facinghistory.org/bullying-case-study-ostracism

\section{Acknowledgment}

We extend appreciation to Mr. Ryan Knowles, Social Outreach Coordinator at The Bully Project, New York City, for providing materials used in the review. 